\title{
MARKET TIMING AND SELECTIVITY PERFORMANCE: A CROSS-SECTIONAL ANALYSIS OF MALAYSIAN UNIT TRUST FUNDS
}

\author{
Soo-Wah Low*
}

\begin{abstract}
:
This study examines the extent to which fund characteristics contributes to explaining fund returns differentiated by managers' stock picking and market timing abilities. The findings show that funds characterized by high exposures to broad market movements have good timing returns but show poor selectivity performance, suggesting the presence of activity specialization among fund managers. It is shown that large funds enhance managers' timing returns, reflecting the efficiencies of large funds in responding to market-wide movements. However, as the size of the fund gets larger, managers find it more challenging to identify worthwhile investments and hence results in poor selectivity performance.
\end{abstract}

Keywords: unit trust fund; market timing; security selection; fund characteristics; fund performance JEL Classification: G11, G29

\section{Introduction}

The unit trust industry in Malaysia has grown tremendously in recent years. As of October 2010, the total net asset value as a percentage to Bursa Malaysia market capitalization stood at 18.91 percent and the industry held total net asset value amounting to RM 227.8 billion in 2010 which is more than five times the amount of RM 43.3 billion, managed in the year 2000 (Federation of Investment Managers Malaysia).

The investment performance of unit trust funds or mutual funds has been vastly researched in both developed and developing countries. While market timing and selectivity performances of mutual funds have been studied extensively in developed countries, there is remarkably little evidence on this aspect in developing countries. Most studies that examined unit trust performance in Malaysia have focused the research on evaluating overall or aggregrated fund performance. Among the limited studies that investigate market timing and security selection abilities of fund managers in Malaysia, none has examined what factors influence two distinct performance components due to market timing and stock selection activities. While fund return is generally observable by investors, the extent to which fund characteristics has an influence on fund return is not obvious to the investing public at large. Since fund's return can be driven by

* Graduate School of Business (UKM-GSB), Universiti Kebangsaan Malaysia (National University of Malaysia), 43600 UKM Bangi Selangor, Malaysia. (swlow@ukm.my). 
manager's selection or and market timing abilities, it would certainly be of interest to investors to know the extent to which fund characteristics influences the selectivity and timing performance components of their funds. In addition, given that a fund manager's stock selection and market timing skills are not observable, information on what fund attributes contributes to selectivity and timing performances would allow managers to better manage their stock selection and market timing activities. That said, this study embarks on the following two objectives. First, the study evaluates the overall risk-adjusted performance and separates the fund performance into selectivity and market timing components. By breaking down the performance components, this study is able to more accurately measure performance based on manager's expertise and thus determine which of the two managerial activities is more rewarding to investors. Second, this study examines to what extent the measures of fund manager's ability to select undervalued securities and to time market movements are related to fund characteristics, such as fund size, expense ratio, investment objective, portfolio turnover ratio, fund risk, fund age, and the growth rate in fund size. The findings expand existing scarce literature on the relationships between fund characteristics and the two separate performance components. The information on what fund attributes contribute to selectivity and market timing components would certainly be of interest to both investors and fund managers. This study is organized as follows. Section 2 discusses the related literature and Section 3 describes the data and methodology employed. Section 4 reports the findings and concluding remarks are offered in Section 5.

\section{Literature Review}

Past research on US and Europe mutual funds that examine the impact of fund characteristics on the overall fund performance have reached mixed conclusions. Studies that report negative relationship between expense ratio and performance for the US mutual funds are Elton et al. (1993), Malkiel (1995), Cahart (1997), Golec (1996). For mutual funds in European countries, Dahlquist et al. (2000), and Otten and Bams (2002) report similar results. More recently, Bialkowski and Otten (2011) find no significant relation between expense ratio and the performance of Polish equity funds. However, fund size is found to be positively related to performance. Dahlquist et al. (2000) in their study of Swedish mutual funds, find that small equity funds are associated with good performance. On the contrary, other studies show that larger fund assets are associated with higher fund returns, for examples, Otten and Bams (2002), Bialkowski and Otten (2011), Fortin and Michelson (2005), and Ferreira et al. (2006). This could possibly suggest the presence of economies of scale in large funds, i.e., fixed overhead expense can be spread over large asset base as the size of assets under management increased. Indro (1999) argues that an uncontrollable growth in size would lead to cost disadvantages that reduce fund return. This argument is supported by Low's (2010) finding on the negative effects of uncontrollable growth in fund size. ${ }^{1}$ On fund age, while Otten and

1 Studies that find no relation between fund size and performance are Grinblatt and Titman (1994), Droms and Walker (1996), Cicotello and Grant (2001), Gallagher and Martin (2005), Low (2010), among others. 
Bams (2002) find that it is negatively related to fund performance, Low (2010) and Bialkowski and Otten (2011) find no evidence of significant relationships. The findings of Low (2010) also indicate that riskier funds are able to generate higher returns. On portfolio turnover, Dahlquist et al. (2000) and Fortin and Michelson (2005) find that it is positively related to fund performance while Ippolito (1989) and Droms and Walker (1996) find no evidence that performance is significantly affected by portfolio turnover. While the aforementioned studies relate fund characteristics to performance, the focus is on the overall fund performance without separating the performance into timing and selectivity components. Fama (1972) segregates managers' forecasting skills into two separate components: security selection and market timing skills. Empirical findings have indicated the presence of security selection and or market timing activities among fund managers. ${ }^{2}$ Although managers' security selection and market timing activities are viewed as important elements that affect fund returns, little attention is given to the determinants of these two performance components. In a comprehensive study of US mutual funds Chen et al. (1992) find that expense ratio and fund size are positively correlated with selectivity but negatively related to timing returns. The opposite directions for the effects of fund characteristics on managerial performance affirm past evidence that there is a trade-off between managers' stock selection and market timing abilities. In Malaysia, while there are several studies that segregate fund performance into managerial selection and market timing components, so far none has examined the extent to which fund characteristics influence performance components attributed to stock selection and market timing activities of managers. ${ }^{3}$ This study builds on a relatively small literature on the relation between fund characteristics variables and the two performance components: selectivity and market timing. The objective is to examine the extent to which these performance measures are related to a fund's fundamental characteristics, such as fund size, expense ratio, investment objective, portfolio turnover ratio, fund risk, age, and fund growth. The findings of this study have important implications for investors and fund managers.

\section{Data and Methodology}

The dataset in this study comprises sixty-five unit trust funds. The data used are net asset value (NAV) of funds, market index prices, rate of return on a 91-day Malaysian Treasury bill, and fund characteristics variables, such as fund expense ratio, fund age, fund investment objective, portfolio turnover, fund size, the growth rate in fund size, and fund's beta value. The return on each fund was calculated using monthly dividendadjusted NAVs. The fund attributes data with the exception of the beta value were sourced from Investor's Guide to Malaysian Unit Trust which provides all relevant

2 Examples are Kon and Jen (1979), Henriksson (1984), Chang and Lewellen (1984), Lee and Rahman (1990), Chen et al. (1992), Kao et al. (1998),Wermers (2000), Rao (2000), Stotz (2007), Abdel-Kader and Kuang (2007).

3 Among the limited studies in Malaysia that investigate market timing and security selection abilities of fund managers are Nassir et al. (1997), Rozali and Abdullah (2006), Low and Ghazali (2005), Low (2010). 
fund attributes data for a five-year study period from January 2000 through December 2004 (Choong, 2005). The beta of the fund was estimated using monthly fund return data. The monthly market return was calculated based on the Kuala Lumpur Composite Index (KLCI). Since the reported Treasury bill rate is an annualized holding period yield, this rate is converted to a monthly equivalent, to be consistent with the monthly returns of unit trust funds and the market return.

This study employs regression analysis in two stages. In the first stage, this study employs the widely used Jensen's (1968) model to calculate the overall fund performance and the model of Henriksson and Merton (1981) to separate the performance into market timing and selectivity components. In the first stage, the regression objective is point estimation, i.e. to obtain coefficient estimates of selectivity and timing measures and not to draw inferences based on the significance of the estimates. In other words, the Jensen's (1968) and Henriksson and Merton's (1981) models are employed to obtain selectivity and timing coefficient estimates for each of the 65 funds. These coefficient estimates are then used as data points (dependent variables) in the secondstage cross-sectional regression analyses that aim to examine the extent to which fund characteristics are related to selectivity and timing performance measures. In the second-stage analyses, the objectives are point estimation as well as hypotheses testing. Hence, the assumption of white noise error term is critical to the valid interpretation of the regression estimates in the cross-sectional models of selectivity and market timing as represented by Equations (3A) and (3B). ${ }^{4}$

However, in the first-stage regression analysis i.e. in the models of Jensen (1968) and Henriksson and Merton (1981), the regression objective is merely to obtain selectivity and timing estimates to be used in the second-stage analyses and not to draw inferences based on the significance of the coefficient estimates. It is thus sufficient that the unbiasedness property of the coefficient estimates remains intact. As highlighted in Gujarati (1995), to establish the unbiasedness of regression estimates it is not necessary that the error term be homoscedastic, and similarly the assumption of non-autocorrrelated errors is also not required to prove that the coefficient estimate is unbiased.

The Jensen's (1968) model is shown by the following regression specification:

$$
\mathrm{R}_{\mathrm{pt}}-\mathrm{R}_{\mathrm{ft}}=\alpha_{\mathrm{J}}+\beta_{\mathrm{p}}\left(\mathrm{R}_{\mathrm{mt}}-\mathrm{R}_{\mathrm{ft}}\right)+\epsilon_{\mathrm{pt}}
$$

Where $R_{p t}$ is the rate of return of the fund at time $t, R_{f t}$ is the contemporaneous rate of return on a risk free asset, $R_{m t}$ is the rate of return of the market portfolio at time $t$. $\beta_{\mathrm{p}}$ is the estimated coefficient for the systematic risk level of the fund, $\alpha_{\mathrm{J}}$ is the Jensen's

4 If the assumptions of uncorrelated residuals and constant variance do not hold, the coefficient estimates will still be unbiased but will no longer be efficient. This lack of efficiency will invalidate any inferences drawn in testing the hypotheses. As a result, $\mathrm{t}$ and $\mathrm{F}$ tests are likely to produce inaccurate statistics and thus inferences made will be misleading (Gujarati, 1995). Thus, diagnostic checks must be performed to ensure that assumptions underlying the regression residuals are not violated. 
performance coefficient, indicating the risk-adjusted performance of the fund, and $\epsilon_{\mathrm{pt}}$ represents the random error term. The above regression equation assumes that the systematic risk of a fund is stationary over time and thus has ignored the existence of timing activities of fund managers. Thus, Jensen's performance model attributes a fund's overall performance entirely to manager's stock selection ability. Since it is highly possible that fund managers engage in market timing activities, Henriksson and Merton (1981) developed a model that allows market timing and selectivity to be evaluated simultaneously. By taking market timing and stock selection abilities into consideration, Henriksson and Merton's (1981) model removes the biases in Jensen's performance estimate that ignores market timing activities of fund managers. For example, if a fund manager is able to successfully time market movement and if such ability is not accounted for in Equation (1), the resulting performance estimate of $\alpha_{\mathrm{J}}$ has indeed attributed the fund performance solely to the manager's selection ability. This has the effect of over-estimating the selection ability of fund manager. Similarly, if the effects of timing activities are not filtered out, a poor market timer manager has the potential of causing a downward bias to the estimate of $\alpha_{\mathrm{J}}$, and thus resulting in an under-estimation of his stock selection ability. Hence, it is important to consider timing and selectivity performance simultaneously in fund performance evaluation.

The market timing model of Henriksson and Merton (1981) is shown by the following regression equation:

$$
\mathrm{R}_{\mathrm{pt}}-\mathrm{R}_{\mathrm{ft}}=\alpha_{\mathrm{S}}+\beta_{1} \mathrm{X}_{\mathrm{t}}+\beta_{2} \mathrm{Y}_{\mathrm{t}}+\epsilon_{\mathrm{pt}}
$$

where $X_{t}=R_{m t}-R_{f t} ; Y_{t}=\max \left[0,-\left(R_{m t}-R_{f t}\right)\right]$, and $\alpha_{S}$ is the abnormal component of the fund's return attributed to manager's security selection ability, after filtering out his market timing ability. In Henriksson and Merton's (1981) model, market timer managers are portrayed as having to forecast time periods in which stocks outperform risk-free assets $\left(\mathrm{R}_{\mathrm{mt}}>\mathrm{R}_{\mathrm{ft}}\right)$ or when risk-free assets outperform stocks $\left(\mathrm{R}_{\mathrm{mt}}<\mathrm{R}_{\mathrm{ft}}\right)$. The two respective periods are known as the up-and down-market periods and are not shown explicitly in Equation (2). In this specification, $\beta_{2}$ measures a manager's market timing ability and a significant positive (negative) estimate of $\beta_{2}$ is indicative of good (poor) market timing ability.

The reading of Equation (2) on market timing ability is better understood if the respective up-and down-market conditions are identified explicitly in the equation. Hence, through a linear transformation, Henriksson and Merton (1981) also develop an alternative but equivalent version of Equation (2) that provides meaningful intuitive understanding. The equivalent of Equation (2) is shown in the following regression specification:

$$
\mathrm{R}_{\mathrm{pt}}-\mathrm{R}_{\mathrm{ft}}=\alpha_{\mathrm{S}}+\beta_{\mathrm{UP}} \mathrm{X}_{\mathrm{ut}}+\beta_{\mathrm{DOWN}} \mathrm{X}_{\mathrm{dt}}+\epsilon_{\mathrm{pt}}
$$


where $X_{\mathrm{ut}}=\max \left[0, \mathrm{R}_{\mathrm{mt}}-\mathrm{R}_{\mathrm{ft}}\right], \mathrm{X}_{\mathrm{dt}}=\min \left[0, \mathrm{R}_{\mathrm{mt}}-\mathrm{R}_{\mathrm{ft}}\right], \beta_{\mathrm{UP}}$ and $\beta_{\mathrm{DOwN}}$ are the up-and down-market Beta respectively. In this specification, the test for market timing is to show that $\beta_{\mathrm{UP}}$ is significantly greater than $\beta_{\mathrm{DOWN}}$. This is equivalent to a significant positive estimate of $\beta_{2}$ in Equation (2). This study employs Equation (2) instead of Equation (2A) because the estimation of market timing ability is directly captured in the coefficient of $\beta_{2}$ in Equation (2), which is equivalent to $\left(\beta_{\mathrm{UP}}-\beta_{\mathrm{DOWN}}\right)$ in Equation $(2 \mathrm{~A})$. Both Equations (2) and (2A) are equivalent and related econometrically. ${ }^{5}$

In the second-stage analyses, to assess the importance and the impact of fund characteristics on managerial selectivity and market timing returns, the $\alpha_{\mathrm{S}}$ and $\beta_{2}$ generated from Equation (2) are regressed on several fund characteristics variables as shown in Equations (3A) and (3B) respectively.

$$
\begin{gathered}
\alpha_{\mathrm{Sj}}=b_{\mathrm{o}}+b_{1} \text { OBJECTIVE }_{\mathrm{j}}+b_{2} \text { RISK }_{\mathrm{j}}+b_{3} \text { TURNOVER }_{\mathrm{j}} \\
+b_{4} \text { EXP }_{\mathrm{j}}+b_{5} \text { SIZE }_{\mathrm{j}}+b_{6} \text { GROWTH }_{\mathrm{j}}+b_{7} \text { AGE }_{\mathrm{j}}+\epsilon_{\mathrm{j}} \\
\beta_{2 \mathrm{j}}=b_{\mathrm{o}}+b_{1} \text { OBJECTIVE }_{\mathrm{j}}+b_{2} \text { RISK }_{\mathrm{j}}+b_{3} \text { TURNOVER }_{\mathrm{j}} \\
+b_{4} \text { EXP }_{\mathrm{j}}+b_{5} \text { SIZE }_{\mathrm{j}}+b_{6} \text { GROWTH }_{\mathrm{j}}+b_{7} \text { AGE }_{\mathrm{j}}+\epsilon_{\mathrm{j}}
\end{gathered}
$$

where $\alpha_{\mathrm{Sj}}$ and $\beta_{2 \mathrm{j}}$ are the selectivity and market-timing measures of fund $\mathrm{j}$ estimated from Equation (2); OBJECTIVE $\mathrm{O}_{\mathrm{j}}$ is dummy variable equals to 1 for aggressive funds and 0 otherwise. Aggressive funds are funds with objectives of growth and high growth while the non-aggresive funds are those with objectives of income and income and growth; RISK $_{\mathrm{j}}$ is the beta value of fund $\mathrm{j}$ and is estimated using monthly return data from January 2000 through December 2004; TURNOVER $\mathrm{j}_{\mathrm{j}}$ is the turnover ratio of fund $\mathrm{j}$, measured by the average total acquisition and disposal of securities for the year as a percentage of the average net asset value of the fund. This ratio captures the aggressiveness of fund manager in managing funds by indicating whether managers buy and sell securities frequently or take a longer term approach to investing. $\mathrm{EXP}_{\mathrm{j}}$ is the jth fund's expenses ratio, which is the portion of the fund's average net asset paid

$5 \quad$ As demonstrated by Henriksson and Merton (1981), in Equation (2), given that $\mathrm{Y}_{\mathrm{t}}=\max$ $\left[0,-\left(R_{m t}-R_{f t}\right)\right]$, hence when $R_{m t}-R_{f t}>0$ or $R_{m t}>R_{f t}$ (i.e. the up-market period), the term $\beta_{2} Y_{t}$ becomes zero because $Y_{t}$ will take the value of zero when $R_{m t}-R_{f t}>0$. As a result, Equation (2) now becomes $R_{p t}-R_{f t}=\alpha_{s}+\beta_{1} X_{t}+\epsilon_{p t}$. Likewise, in Equation (2A), given that $X_{d t}=\min \left[0, R_{m t}-R_{f t}\right]$, hence when $\mathrm{R}_{\mathrm{mt}}-\mathrm{R}_{\mathrm{ft}}>0$ (i.e. the up-market period), the term $\beta_{\mathrm{DowN}} X_{\mathrm{dt}}$ becomes zero because $X_{\mathrm{dt}}$ will take the value of zero when $R_{m t}-R_{f t}>0$. Accordingly, the resulting Equation (2A) can now be written as $\mathrm{R}_{\mathrm{pt}}-\mathrm{R}_{\mathrm{ft}}=\alpha_{\mathrm{S}}+\beta_{\mathrm{UP}} \mathrm{X}_{\mathrm{ut}}+\epsilon_{\mathrm{pt}}$. Hence, in the up-market period, when $\mathrm{R}_{\mathrm{mt}}>\mathrm{R}_{\mathrm{ft}}$, the comparison between Equations (2) and (2A) suggests that $X_{t}$ in Equation (2) is identical to $X_{u t}$ in Equation (2A), technically implying that $\beta_{1}=\beta_{\mathrm{UP}}$. Likewise, when market condition is defined as the downmarket period, i.e. when $\mathrm{R}_{\mathrm{mt}}-\mathrm{R}_{\mathrm{ft}}<0$ or $\mathrm{R}_{\mathrm{mt}}<\mathrm{R}_{\mathrm{ft}}$, in Equation (2), $\mathrm{X}_{\mathrm{t}}=-\mathrm{Y}_{\mathrm{t}}$ and through the relevant substitution, Equation (2) becomes $R_{p t}-R_{f t}=\alpha_{S}+\beta_{1} X_{t}-\beta_{2} X_{t}+\epsilon_{p t}$ or simply $R_{p t}-R_{f t}=\alpha_{S}+\left(\beta_{1}-\beta_{2}\right)$ $\mathrm{X}_{\mathrm{t}}+\epsilon_{\mathrm{pt}}$. Similarly, Equation (2A) can now be rewritten as $\mathrm{R}_{\mathrm{pt}}-\mathrm{R}_{\mathrm{ft}}=\alpha_{\mathrm{S}}+\beta_{\mathrm{DOwN}} \mathrm{X}_{\mathrm{dt}}+\epsilon_{\mathrm{pt}}$. Accordingly, $\beta_{\mathrm{DOwN}}$ in Equation (2A) is equal to the difference between $\beta_{1}$ and $\beta_{2}$ in Equation (2), i.e. $\beta_{\text {DOWN }}=\left(\beta_{1}-\beta_{2}\right)$. Since $\beta_{1}=\beta_{\mathrm{UP}}$, and $\beta_{2}=\beta_{1}-\beta_{\mathrm{DOWN}}, \beta_{2}$ now equals to $\beta_{\mathrm{UP}}-\beta_{\mathrm{DOWN}}$, i.e. $\beta_{2}=\left(\beta_{\mathrm{UP}}-\beta_{\text {DOWN }}\right)$. 
for management fees, trustee fees, audit fee and other administrative fee involved in operating the fund. Expense ratio and turnover ratio capture the costs associated with the acquiring of and trading on information. $\mathrm{AGE}_{\mathrm{j}}$ is the natural logarithm of the fund's age since inception until December 2004; $\mathrm{SIZE}_{\mathrm{j}}$ is the natural logarithm of the fund's year

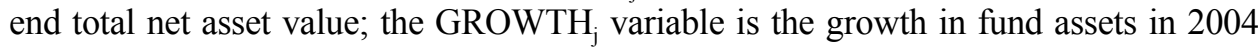
and it is measured as the percentage change of fund assets over the previous year 2003.

Since the objectives of the second-stage analyses are point estimation as well as hypotheses testing, the assumption of white noise error term is critical to the valid interpretation of the regression estimates. That said, diagnostic checks were performed on both the cross-sectional models of selectivity and market timing (Equations (3A) and (3B) respectively) to ensure that the assumptions underlying the regression residuals are not violated. The presence of heteroscedasticity is checked using a test employed by White (1980) and the Durbin-Watson D test is performed to check for the potential problem of first-order autocorrelation in the residuals.

\section{Empirical Results and Discussion}

In the selectivity and market timing models as shown in Panels A and B of Table 3, the White chi-square test of first and second moment specification show insignificant chi-square statistics, suggesting that the null hypothesis cannot be rejected. ${ }^{6}$

For the test of serial correlation, the null hypothesis is, there is no first-order autocorrelation in the residuals. The Durbin-Watson $d$ statistics for the selectivity and timing models are found to be 1.537 and 1.645, respectively. From the Durbin-Watson tables in Gujarati (1995) pp. 818-819, based on 65 observations and 7 explanatory variables (excluding the intercept), at the $5 \%$ level the critical $d$ values are $d_{L}=1.370$ and $d_{U}=1.843$. Since the estimated $d$ statistics in both models fall in the indecisive zone, one cannot conclude whether autocorrelation does or does not exist. However, to exercise caution, it is assumed that autocorrelation does exist in both the selectivity and timing models. ${ }^{7}$ The main problem associated with the presence of autocorrelation is unreliable $t$-statistics and variables may appear too significant using conventional $t$-statistics. Nevertheless, a corrected estimate of the standard error will rectify the problem. To ensure that inferences made from the regression results are unaffected by the serial correlation problem, this study reports $t$-statistics based on the standard errors of estimated coefficients after adjusting for serial correlation using the procedure of Newey and West (1987).

6 In White's (1980) test, the null hypothesis is a joint hypothesis, testing whether the model's specification of the first and second moments of the dependent variable is correct. That is, the null hypothesis contends that the residuals are homoscedastic, independent of the explanatory variables, and that the model is correctly specified. Gujarati (1995) describes White's test for heteroscedascity in pages 379-380.

7 Like heteroscedascity in the presence of autocorrelation the coefficient estimates will still maintain their unbiasedness and consistency properties but will no longer have a minimum variance. This lack of inefficiency will invalidate any inferences drawn in testing the hypotheses (Gujarati, 1995). 
Given the potential problems of multicollinearity among the fund attributes variables, a diagnostic check was performed using variance inflation factors (VIFs). As a rule of thumb, a VIF $>10$ is taken as an indicator of the presence of multicollinearity and the diagnostic results show that none of the fund characteristics variables has a value greater than 10 .

\section{(i) The summary statistics of performance measures}

Table 1 reports summary statistics for unit trust performance measures estimated from the models of Jensen (1968), and Henriksson and Merton (1981). In Jensen's (1968) model, $\alpha_{\mathrm{J}}$ has a mean value of -0.0024 and it measures selectivity performance when market timing ability is not taken into consideration. Since the market timing component is not accounted for in the model, the estimate of $\alpha_{\mathrm{J}}$ attributes the fund's overall performance entirely to selectivity performance. As a result, in the presence of positive timing returns, the Jensen's model would over-estimate the selectivity performance and cause an upward bias in the estimate of $\alpha_{\mathrm{J}}$.

Henriksson and Merton's (1981) model provides the separate selectivity and market timing components as shown by the estimates of $\alpha_{\mathrm{S}}$ and $\beta_{2}$, respectively. On average, manager's market timing activity contributes positively to fund's return $\left(\beta_{2}=0.0713\right)$ and the return attributed to a manager's stock selection ability after filtering out his market timing activity is captured by $\alpha_{S}=-0.004$. By taking both market timing and stock selection abilities into consideration, Henriksson and Merton's (1981) model removes the biases in Jensen's estimate of $\alpha_{\mathrm{J}}$ which ignores market timing activities of fund managers. The negative mean values of $\alpha_{\mathrm{J}}$ and $\alpha_{\mathrm{S}}$ suggest that on average, fund managers' stock selection skills are not adding value to fund returns. Comparison of the two selectivity measures indicates that $\alpha_{\mathrm{J}}=-0.0024$ is less negative than $\alpha_{s}=-0.004$. Given that the Jensen's model does not filter out the effects of market timing activities, the presence of positive timing return as indicated by a positive value of $\beta_{2}$, has somewhat mitigated the degree of negative return associated with selection skill. Thus, in the presence of positive timing returns, the Jensen's model has in fact over-estimated the selection ability of manager as shown by a lower negative value of $\alpha_{\mathrm{J}}$. In Henriksson and Merton's (1981) model, when fund performance is broken down into selectivity and timing components, i.e. after filtering out the positive timing performance as indicated by $\beta_{2}$, a manager's poor selectivity performance is now revealed by a negative value of $\alpha_{\mathrm{S}}$ that is more negative than $\alpha_{\mathrm{J}}{ }^{8}$

8 Past studies on Malaysian mutual funds by Nassir et al. (1997) and Low and Ghazali (2005) show that managers' market timing activities are not adding value to funds' return given the timing estimates of -0.3666 , and -0.1483 , respectively. The corresponding estimates for selectivity are 0.0049 and -0.00071 . Rozali and Abdullah (2006) find that the average selectivity returns for income, balanced, and growth funds are $-0.0058,-0.0050$, and -0.0105 , respectively. The corresponding timing returns are $-0.4433,-0.6172$, and -0.3117 . Low (2007) finds little variations in selectivity and timing estimates across different market benchmarks. In comparison with other markets, Chen et al. (1992) findings for the US mutual funds show that on average, managers have positive selectivity of 0.00138 and negative timing returns of -0.0068 . Consistent with earlier studies on German funds, Stotz (2007) find that managers on average do not generate positive returns from stock selection and market timing activities with estimates of -0.0014 and -0.0016 respectively. 


\section{(ii) The correlation between performance measures and fund characteristics}

Table 2 presents pairwise correlations for performance measures and fund characteristics. Selectivity and market timing measures have a high significant correlation coefficient of -0.881 , suggesting that there is a trade-off between a fund manager's stock selection and market timing abilities. Such correlation structure is also an evidence of activity specialization among fund managers, implying that no manager can excel in both activities. Selectivity performance is shown to be inversely related to fund risk as measured by beta with a correlation coefficient of -0.603 . This suggests that risky funds characterized by high exposures to broad market movements have poor selectivity returns. It is shown that managerial selection ability has a modest correlation of -0.244 with fund size. Market timing performance is shown to be highly and positively correlated with fund risk with a correlation coefficient of 0.700 , as opposed to the coefficient of -0.603 observed for selectivity performance. This suggests that funds with high exposures to broad market movements seem to be better managed by managers with market timing abilities. Similar to selectivity measure, the timing performance is also found to be modestly correlated with fund size but in a positive direction. Fund size is negatively and significantly correlated with portfolio turnover, expense ratio, and fund age. The correlation coefficients are -0.337 and -0.367 for portfolio turnover and expense ratio respectively suggesting that larger funds trade less frequently and have lower expense ratio than smaller funds. The negative correlation of 0.427 between fund size and fund age suggests that older funds are smaller in size. The number of years that funds have been in existence is shown to be negatively correlated with portfolio turnover.

\section{(iii) The relationships between selectivity performance and fund characteristics}

In Table 3, Panel A reports the cross-sectional results of selectivity performance as represented by Equation (3A). The selectivity regression model is significant and has adjusted R-squared of 0.429 suggesting that fund characteristics variables explain almost 43 percent of the cross-section variations in managers' selectivity performance. The significant negative coefficient of fund size suggests that as the size of the fund becomes larger, it becomes more difficult for fund manager to find worthwhile investments alternatives which eventually has the effect of diminishing managerial selectivity performance. This could possibly be the reason that managers managing large funds are associated with inferior security selection decisions. Such finding is consistent with the argument of Ferreira et al. (2006) that the effects of managerial skills become diluted as fund size increases.

On fund risk, since it is measured using beta, this fund risk variable captures a fund's exposure to market risk or broad market movement. The coefficient of fund risk is found to be negatively and significantly related to selectivity performance, suggesting that risky funds characterized by high exposures to broad market movements seem to show poor selectivity returns. Given that market movements are generally unpredictable, funds with high exposures to market risk make it all the more challenging for managers 
to correctly select stocks that would maximize funds' returns. That is, managers whose activity specialization is stock selection are likely to show poor selectivity performance when managing funds with high exposures to broad market movements. Funds with such characteristics may be better managed by managers with market timing abilities who are believed to be more capable in exploiting market-wide movements than managers with stock selection abilities. There is weak evidence that growth in fund size is positively correlated with selectivity performance. The findings show that fund objective, portfolio turnover, expense ratio, and fund age play no significant roles in influencing the variation in selectivity performance.

\section{(iv) The relationships between timing performance and fund characteristics}

The Panel B of Table 3 reports the cross-sectional results of timing performance. The regression model is significant with adjusted R-squared of 0.600 indicating that fund attributes explain 60 percent of the variations in market timing performance. The coefficients of fund size and fund risk are highly significant and are shown to be positively related to timing return. The directions of the relationships are opposite to those found for selectivity performance as reported in Panel A. This somewhat reinforces the findings of past studies that if a manager is engaged in both stock selection and market timing activities, a trade-off exists between the two abilities. The finding that larger funds have better timing returns than smaller ones implies that, large funds put managers in a better position to exploit the predictability of market returns to increase fund returns. This possibly reflects the efficiencies of large funds in responding to changes in broad market movements. In other words, if a change in market trend is anticipated by fund manager, it would cost less to make adjustment to the portfolio holding possibly due to the existence of economies of scale among large funds. Hence, this contributes to increasing fund returns from the market timing activities of fund managers.

The coefficient of fund risk is positive and highly significant, suggesting that funds with high exposures to broad market movements have better timing returns than those with low exposures to market risk. This is not surprising since market timing performance captures manager's ability to respond to changes in broad market movements. The findings that fund risk is negatively related to selectivity (in Panel A) and positively related to timing (in Panel B) suggest that there exists activity specialization among fund managers and managers of high beta funds should focus their activities on forecasting future market movements instead of searching for mispriced securities.

There is weak evidence that expense ratio enhances a manager's market timing return although no such evidence is found for managerial selectivity performance. Money and resources expended on research seem useful in predicting market-wide movements. This evidence suggests that it may be relatively easier for fund manager to time the broad market movements than to pick undervalued stocks. On fund objective, there is also weak evidence that aggressive funds with the objectives of growth and high growth are negatively correlated with timing returns. The findings also reveal 
that portfolio turnover, fund growth, and the number of years that funds have been in existence have no significant relations to a manager's market timing performance.

While it is agreeable that the obtained R-squared in both the selectivity and market timing regressions are not very high i.e. $43 \%$ and $60 \%$ respectively, it is a common experience in empirical analysis that there is bound to be some randomness in the dependent variables that cannot be explained by the explanatory variables. In a related study, Chen et al. (1992) show that their models explain approximately $34 \%$ and $28 \%$ of the variations in managers' selectivity and market timing returns respectively. At best, the present study has employed the relevant fund characteristics variables found in prior research that affect the variations in managerial selectivity and timing measures.

\section{Conclusions}

The objective of this study is to explore which if any of a fund's fundamental characteristics are helpful in identifying fund with superior investment decisions driven by managers' activities of selecting stocks and timing the broad market movements. The findings show that fund risk is negatively related to selectivity but positively related to timing returns, suggesting that managers whose activity specialization is stock selection are likely to show poor performance when managing funds with high exposures to broad market movements. In other words, funds with such attributes are better managed by market timer managers who are skillful at taking advantage on market-wide movements. On fund size, it is shown that fund managers of large funds can better exploit the predictability of broad market movements, reflecting the cost efficiencies associated with economies of scale of large funds. Nevertheless, the result also suggests that as the size of the funds becomes larger, it becomes more difficult for fund managers to find worthwhile investments and thus resulting in low selectivity returns. These results deviate from findings of the US mutual funds market as reported by Chen et al. (1992) where fund size is found to be positively associated with selectivity performance but negatively related to timing returns.

The findings of this study are useful to investors and provide potential policy implications to the fund management industry. Since the investment actions of managers are not directly observable by investors, the findings on what fund characteristics affect managerial performance components provide useful insights to investors in making investment decisions. From the perspective of fund management companies, the findings imply that fund managers whose core activities are to formulate market timing strategies are in better positions to manage funds that are large in size and have high exposures to broad market movements. The observed opposite effects of fund characteristics variables on stock selection and market timing returns also reaffirm past evidence that a trade-off exists between managers' security selection and market timing abilities. The findings of this study expand existing scarce literature that highlight the important influence of fund characteristics on managerial selectivity and market timing returns. 
Table 1

Summary Statistics for Unit Trust Performance

\begin{tabular}{|l|c|c|c|}
\hline \multirow{2}{*}{ Mean } & Jensen's (1981) Model & Henriksson and Merton's (1981) Model \\
\cline { 2 - 4 } & $\boldsymbol{\alpha}_{\mathrm{j}}$ & $\boldsymbol{\alpha}_{\mathbf{s}}$ & $\boldsymbol{\beta}_{\mathbf{2}}$ \\
\hline Standard Deviation & -0.0024 & -0.0041 & 0.0713 \\
\hline Medium & 0.0038 & 0.0074 & 0.3434 \\
\hline Minimum & -0.0021 & -0.0033 & 0.0230 \\
\hline Maximum & -0.0103 & -0.0262 & -0.7168 \\
\hline
\end{tabular}

Table 2

Pairwise Correlation Coefficients

\begin{tabular}{|l|l|l|l|l|l|l|l|l|}
\hline & Selectivity & Timing & Risk & Turnover & Exp. & Size & Growth & Age \\
\hline Selectivity & 1.000 & & & & & & & \\
\hline Timing & $-0.881^{* *}$ & 1.000 & & & & & & \\
\hline Risk & $-0.603^{\star *}$ & $0.700^{* *}$ & 1.000 & & & & & \\
\hline Turnover & -0.018 & -0.102 & 0.035 & 1.000 & & & & \\
\hline Exp. & -0.124 & 0.008 & -0.006 & $0.298^{* *}$ & 1.000 & & & \\
\hline Size & $-0.244^{* *}$ & $0.327^{* *}$ & 0.035 & $-0.337^{* *}$ & $-0.367^{* *}$ & 1.000 & & \\
\hline Growth & 0.178 & -0.193 & -0.027 & $0.215^{*}$ & -0.002 & -0.074 & 1.000 & \\
\hline Age & 0.174 & -0.200 & -0.012 & $-0.285^{* *}$ & 0.117 & $-0.427^{* *}$ & 0.009 & 1.000 \\
\hline
\end{tabular}

Notes: $* *$ and $*$ denote statistical significance at the 0.05 or less and 0.10 levels respectively. 
Table 3

Cross-Sectional Regression Results

\begin{tabular}{|c|c|c|c|c|}
\hline \multicolumn{5}{|c|}{$\begin{array}{l}\text { Panel A } \\
\text { Dependent variable: Selectivity Performance }\end{array}$} \\
\hline Variable & Coefficient & t-Statistic & $\operatorname{Pr}>|T|$ & VIF \\
\hline Constant & 2.470 & $2.929^{\star *}$ & 0.005 & 0.000 \\
\hline OBJECTIVE & 0.054 & 0.384 & 0.702 & 1.269 \\
\hline RISK & -1.823 & $-5.118^{\star \star}$ & 0.000 & 1.051 \\
\hline TURNOVER & -0.044 & -0.354 & 0.724 & 1.709 \\
\hline EXP. & -0.539 & -1.332 & 0.188 & 1.216 \\
\hline SIZE & -0.140 & $-2.671^{* *}$ & 0.009 & 1.801 \\
\hline GROWTH & 0.004 & $1.652^{*}$ & 0.104 & 1.062 \\
\hline AGE & 0.095 & 0.744 & 0.460 & 1.790 \\
\hline F Value $=7.88$ & Prob $>F=0.000$ & Adjusted $\mathrm{R} 2=0.429$ & & $\mathrm{~N}=65$ \\
\hline \multicolumn{5}{|c|}{ White's (1980) Test of First Moment and Second Moment Specification: } \\
\hline $\mathrm{DF}=34$ & \multicolumn{2}{|c|}{$\chi^{2}=28$} & \multicolumn{2}{|c|}{ Prob $>\chi^{2}=0.717$} \\
\hline \multicolumn{5}{|c|}{$\begin{array}{l}\text { Panel B } \\
\text { Dependent variable: Market Timing Performance }\end{array}$} \\
\hline \multicolumn{5}{|c|}{$\begin{array}{c}\beta_{2 \mathrm{j}}=b_{\mathrm{o}}+b_{1} \text { OBJECTIVE }_{\mathrm{j}}+b_{2} \text { RISK }_{\mathrm{j}}+b_{3} \text { TURNOVER }_{\mathrm{j}}+b_{4} \text { EXP }_{\mathrm{j}}+b_{5} \text { SIZE }_{\mathrm{j}}+ \\
b_{6} \text { GROWTH }_{\mathrm{j}}+b_{7} \text { AGE }_{\mathrm{j}}+\in_{\mathrm{j}}\end{array}$} \\
\hline Variable & Coefficient & t-Statistic & $\mathrm{Pr}>|\mathrm{T}|$ & VIF \\
\hline Constant & -1.039 & $-3.261^{* *}$ & 0.002 & 0.000 \\
\hline OBJECTIVE & -0.098 & $-1.727^{\star}$ & 0.089 & 1.269 \\
\hline RISK & 1.015 & $6.901^{* *}$ & 0.000 & 1.051 \\
\hline TURNOVER & -0.068 & -0.938 & 0.352 & 1.709 \\
\hline EXP. & 0.161 & $1.773^{*}$ & 0.082 & 1.216 \\
\hline SIZE & 0.066 & $2.844^{* *}$ & 0.006 & 1.801 \\
\hline GROWTH & -0.002 & -1.303 & 0.198 & 1.062 \\
\hline AGE & -0.087 & -1.511 & 0.136 & 1.790 \\
\hline$F$ Value $=14.74$ & Prob $>F=0.000$ & Adjusted $R^{2}=0.600$ & & $\mathrm{~N}=65$ \\
\hline \multicolumn{5}{|c|}{ White's (1980) Test of First Moment and Second Moment Specification: } \\
\hline$D F=34$ & \multicolumn{2}{|c|}{$\chi^{2}=34.36$} & \multicolumn{2}{|c|}{ Prob $>\chi^{2}=0.4506$} \\
\hline
\end{tabular}

Notes:

1. ${ }^{* *}$ and * denote statistical significance at the 0.05 or less and 0.10 levels respectively.

2. $t$-statistics are based on the standard errors after adjusting for serial correlation using the procedure of Newey and West (1987). 


\section{References}

Abdel-Kader, M., Kuang, Y. (2007), "Risk-Adjusted Performance, Selectivity, Timing Ability and Performance Persistence of Hong Kong Mutual Funds." Journal of Asia-Pacific Business, Vol. 8, No. 2, pp. 25-58.

Bialkowski, J., Otten, R. (2011), "Emerging Market Mutual Fund Performance: Evidence for Poland." North American Journal of Economics and Finance, Vol. 22, No. 2, pp. 118-130.

Carhart, M. (1997), “On Persistence in Mutual Fund Performance.” Journal of Finance, Vol. 52, No. 1, pp. 57-82.

Chang, E. C., Lewellen, W. G. (1984), "Market Timing and Mutual Fund Investment Performance." Journal of Business, Vol. 57, No. 1, pp. 57-72.

Chen, C. R., Lee, C. F., Rahman, S., Chan, A. (1992), "A Cross-Sectional Analysis of Mutual Funds" Market Timing and Security Selection Skill." Journal of Business Finance \& Accounting, Vol. 19, No. 5, pp.659-675.

Choong, D. (2005), Investor's Guide to Malaysian Unit Trust. $3^{\text {rd }}$ Edition, Sage Publishing.

Ciccotello, C. S., Grant, C. T. (2001), "Equity Fund Size and Growth: Implications for Performance and Selection." Financial Services Review, Vol. 5, No. 1, pp. 1-12.

Dahlquist, M., Engstrom, S., Soderlind, P. (2000), "Performance and Characteristics of Swedish Mutual Funds." Journal of Financial and Quantitative Analysis, Vol. 35, No. 3, pp. 409-423.

Droms, W. G., Walker, D. A. (1996), "Mutual Fund Investment Performance." Quarterly Review of Economics and Finance, Vol. 36, No. 3, pp. 347-363.

Elton, G., Das, S., Hlavka, M. (1993), "Efficiency with Costly Information: A Reinterpretation of Evidence from Managed Portfolio." Review of Financial Studies, Vol. 6, pp.1-22.

Fama, E. F. (1972), “Components of Investment Performance." Journal of Finance, Vol. 27, pp.551- 567.

Federation of Investments Managers Malaysia, available at http:// www.fimm.com.my.

Ferreira, M. A., Miguel, A. F., Ramos, S. (2006), "The Determinants of Mutual Fund Performance: A Cross-Country Study." Swiss Finance Institute Research Paper Series N06-30.

Fortin, R., Michelson, S. (2005), "Active International Mutual Fund Management: Can Managers Beat the Index?" Managerial Finance, Vol. 31, No. 1, pp. 41-51.

Gallagher. D., Martin, K. (2005), "Size and Investment Performance: A Research Note." Abacus, Vol. 41, No. 1, pp. 55-65.

Golec, J. H. (1996), "The Effects of Mutual Fund Managers' Characteristics on their Portfolio Performance, Risk, and Fees." Financial Services Review, Vol. 5, No. 2, pp. 133-148.

Grinblatt, M., Titman, S. (1994), "A Study of Monthly Mutual Fund Returns and Portfolio Performance Evaluation Techniques." Journal of Financial and Quantitative Analysis, Vol. 29, No. 3, pp. 419-444.

Henriksson, R. D. (1984), "Market Timing and Mutual Fund Performance: An Empirical Investigation." Journal of Business, Vol. 57, No. 1, pp. 73-96.

Henriksson, R. D., Merton, R. C. (1981), "On Market Timing and Investment performance. II. Statistical Procedures for Evaluating Forecasting Skills." Journal of Business, Vol. 54, No. 4, pp. 513-533.

Gujarati, D. N. (1995), Basic Econometrics. $3^{\text {rd }}$ ed. New York: McGraw-Hill.

Indro, D. C., Jiang, C. X., Hu, M. Y., Lee, W. Y. (1999), "Mutual Fund Performance: Does Fund Size Matter?" Financial Analysts Journal, Vol. 55, No. 3, pp.74-87.

Ippolito, R. A. (1989), "Efficiency with Costly Information: A Study of Mutual Fund Performance 1965-1984." Quarterly Journal of Economics, Vol. 104, No. 1, pp. 1-23. 
Jensen, M. C. (1968), "The Performance of Mutual Funds in the Period 1945-1964." Journal of Finance, Vol. 23, No. 2, pp. 389-416.

Kao, G. W., Cheng, L. T. W., Chan, K. C. (1998), "International Mutual Fund Selectivity and Market Town Market Conditions." Financial Review, Vol. 33, pp. 127-144.

Kon, S. J., Jen, F. C. (1979), "The Investment Performance of Mutual Funds: An Empirical Investigation of Timing, Selectivity, and Market Efficiency." Journal of Business, Vol. 52, No. 2, pp. 263-289.

Lee, C. F., Rahman, S. (1990), "Market Timing, Selectivity, and Mutual Fund Performance: An Empirical Investigation." Journal of Business, Vol. 63, No. 2, pp. 261-278.

Low, S-W., Ghazali, N. A. (2005), "An Evaluation of the Market-Timing and Security- Selection Performance of Mutual Funds: The Case of Malaysia." International Journal of Management Studies, Vol. 12, No. 1, pp. 97-115.

Low, S-W. (2007), "Malaysian Mutual Fund Performance during up and down Market Conditions: A Comparison of Market Benchmark." Managerial Finance, Vol. 33, pp. 154-166.

Low, S-W. (2010), "Relationship between Fund Performance and Characteristics of the Malaysia Unit Trust Fund." Singapore Management Review, Vol. 32, No. 1, pp. 29-43.

Malkiel, B. G. (1995), "Returns from Investing in Equity Mutual Funds 1971-1991." Journal of Finance, Vol. 50, No. 2, pp. 549-572.

Nassir, A. M., Mohamed, S., Ngu, M. H. (1997), "Selectivity and Timing: Evidence from the Performance of Malaysian Unit Trusts." Pertanika Journal of Social Science \& Humanities, Vol. 5, No. 1, pp. 45-57.

Newey, W. K., West, K. (1987), "A Simple Positive-Definite Heteroskedasticity and Autocorrelation Consistent Covariance Matrix." Econometrica, Vol. 55, No. 3, pp. 703-708.

Otten, R., Bams, D. (2002), "European Mutual Fund Performance." European Financial Management, Vol. 8, No. 1, pp. 75-101.

Rao, S. P. U. (2000), "Market Timing and Mutual Fund Performance." American Business Review, Vol. 18, pp.75-79.

Rozali, M. B., Abdullah, F. (2006), "Market Timing and Security Selection Performance of Mutual Funds: Evidence from Malaysia." Faculty of Finance and Banking, Universiti Utara Malaysia. Available at http://bai2006.atisr.org/CD/Papers/2006bai6120.doc.

Stotz, O. (2007), "Selection, Market Timing and Style Timing of Equity Mutual Funds - Evidence from Germany." Zeitschrift Fur Betriebswirtschaft, Vol. 77, No. 1, pp. 51-73.

Wermers, R. (2000), "Mutual Fund Performance: an Empirical Decomposition into Stock-Picking Talent, Style, Transaction Costs and Expenses." Journal of Finance, Vol. 55, No. 4, pp. 1655-1695.

White, H. (1980), "A Heteroskedasticity-Consistent Covariance Matrix Estimator and a Direct Test for Heteroskedasticity." Econometrica, Vol. 48, pp.817-833. 